\title{
COMPARATIVE ANALYSIS OF ISLAMIC BANKING FINANCIAL PERFORMANCE BEFORE AND DURING THE COVID 19 PERIOD IN INDONESIA
}

\author{
Nofinawati ${ }^{1}$, Abdul Nasser Hasibuan ${ }^{2}$, Dinda Sildya $^{3}$, Ferdy Kurniawan ${ }^{4}$, \\ hasibuanabdulnasser@iain-padangsidimpuan.ac.id ${ }^{1}$
}

\begin{abstract}
Purpose: This research has objective to compare the Islamic banking financial performane between before and during the Covid 19 period and to specify the variables that determine financial performance such as CAR, NPF, FDR, and Net Profit.

Research Methodology: Data analysis tools in this research used quantitative descriptive analysis which takes its data from the www.ojk.go.id at Islamic banking statistic, 6 month before covid 19 and 6 month during the covid 19 period. The data management by using quantitative descriptive study which means to analysis and describe a situation or phenomenon.

Findings: the conclusion of this reseach is the existence of some differences in the magnitude of the ratios of Islamic banking financial performance before and during the covid 19 period in Indonesia.

Originality: The result of this research is useful for improving Islamic banking performance in Indonesia.
\end{abstract}

Keywords: Comparative, Financial Performance, Islamic Banking, Covid 19 


\section{Introduction}

In recent years, the existence of Islamic banking has increasingly become a very important alternative financial institution for the real sector community. This is because Islamic banks have played a role in encouraging profit-sharing practices and avoiding the practice of usury (interest). But at the end of 2019 to 2020, a virus that hit all countries in the world, causing the economy to decline. The virus is Corona Virus Disease 19 or commonly known as Covid-19. This virus is one of the pandemics according to WHO, which is a virus that can be transmitted very quickly. This virus emerged from Wuhan City, Hubei Province, China. Outside China, Covid 19 has infected 46.5 million cases and 1.2 million people have died. Indonesia is one of the countries affected by the Covid-19 pandemic. Based on information obtained as of October 2020, there were 413,000 confirmed cases of Covid-19, of which 13,943 died.

A policy made during this pandemic is to stay indoors, which has led to a slowdown in economic growth. One of the industries affected is the banking industry due to the policy of delaying installment payments for customers to avoid the spread of Covid-19. This led to a crisis in the banking industry. The impact of Covid-19 does not only have an impact on public health, but also affects the people's economy. The Covid-19 pandemic has caused a decline in the global and domestic economy. Not only weakened but also slowed the pace of the national economy.

During the Covid 19 pandemic, which caused a decline in global economic growth, which ultimately affected banking performance due to several possible risks, namely non-performing financing risk (NPF), market risk and liquidity risk. In an article written by Hasibuan, Abdul Nasser et al (2017) said Signal Theory is that the delivery of information to information users (customers) will determine the overall performance of a company, by sending these signals will give customers confidence in using banking services (hasibuan et al., 2017).

Therefore, these risks will ultimately affect the performance and profitability of Islamic banking. With the existence of several risks faced by Islamic banking, this study will look at the comparison of the financial performance of Islamic banking before and after Covid 19, in order to see the level of customer confidence in the use of banking services as seen through financial performance (CAR, NPF, FDR, Net Profit) in Islamic banking in Indonesia.

\section{Literature Review}

\section{Signal Theory}

Signal theory explains why companies have a tendency to provide financial information to external parties, because of the asymmetric information between companies and investors. Lack of information from outside parties will cause outsiders to protect themselves by giving the 


\section{Nofinawati, Abdul Nasser Hasibuan, Dinda Sildya, Ferdy Kurniawan}

Comparative Analysis of Islamic Banking Financial Performance Before and During the Covid 19 Period in Indonesia

company a low value. Submitting financial reports to outsiders will increase confidence in the company.

According to Kasmir (2004) interested parties in knowing the results of bank information include is Shareholders, to see the progress of the bank's performance, to find an overview of the amount of dividends to be received; Government, to determine bank compliance in implementing monetary policy; Management, to see the performance of the bank's success in achieving targets; Employees, to find out what condition the bank should be so that they are their performance; The public at large, to find out the health condition of the bank, so that they still believe in using the bank's services.

\section{Financial performance}

Financial performance is an analysis carried out to see the extent to which a company has implemented financial implementation rules properly. According to Zarkasyi that: "Financial performance is something that is produced or the result of work achieved by a company". Furthermore, Munawir stated that the company's financial performance is one of the bases for assessing the company's financial condition which is based on an analysis of the company's financial ratios. Interested parties really need the results of the measurement of the company's financial performance in order to see the company's condition and the company's success rate when carrying out its operational activities (Iswardi \& Amanah, 2015).

From the above understanding, it can be concluded that financial performance is showing a good and bad picture of the company regarding the level of success achieved by a company in running its operations. The company is getting healthier if the company's financial performance is getting better.

\section{CAR (Capital Adequacy Ratio)}

CAR is the ratio of bank performance to measure the adequacy of capital owned by the bank to support assets that carry risk or generate risk, for example, bank loans (Pravasanti, 2018). CAR is a ratio that shows the extent to which all bank assets that contain risk (credit, investment, securities, claims on other banks) are also financed from the bank's own capital funds besides obtaining funds from sources outside the bank, such as funds from the public, loans, and others. Based on SE BI Number 12/11 / DPNP dated March 31, 2010, the CAR ratio can be formulated as follows:

$$
C A R=\frac{\text { Bank capital }}{A T M R} \times 100 \%
$$

CAR is an indicator of a bank's ability to cover the decline in its assets as a result of bank losses caused by risky assets. This CAR is based on the principle that every risky investment must 
be provided with an amount of capital equal to the percentage of the total investment, the greater the ratio the better the capital position. In accordance with the standards set by the Bank of International Settlements (BIS), all banks in Indonesia are required to provide a minimum capital of $8 \%$ of risk-weighted assets.

\section{NPF (Non Performing Financing)}

$\mathrm{NPF}$ is the ratio used to calculate the level of non-performing financing extended by Islamic banks to their financing customers. Non-performing financing can arise as a result of settlement risk arising from failure to deliver cash and / or financial instruments on the settlement date that has been agreed upon from the sale and / or purchase transaction of financial instruments. The risk of problem financing can be measured using the Non Performing Financing (NPF) ratio. NPF shows the ability of bank management in managing problem financing at the bank. The higher the NPF, the worse the quality of bank financing. The risk of financing received by the bank is due to the uncertainty of the return on financing that has been given (Pravasanti, 2018).

$$
N P F=\frac{\text { Troubled Financing }}{\text { Total Financing }} \times 100 \%
$$

\section{FDR (Financing to Deposit Ratio)}

FDR is a comparison between the amount of financing channeled by Islamic banks with Third Party Funds obtained by the bank. This FDR can indicate the ability of the bank to collect third party funds and distribute them to the applicant. FDR is also a bank's ability to channel funds in the form of financing and then returned to depositors based on the amount of financing channeled and acts as a source of liquidity. If the amount of financing is getting bigger, the return that the bank will get will also increase, because the addition of return will automatically increase profits. The formula for the Financing to Deposit Ratio (FDR) liquidity ratio is:

$$
F D R=\frac{\text { Total financing }}{\text { Amount of Funds Received by the Bank }} \times 100 \%
$$

FDR is actually the same as the Loan to Deposit Ratio (LDR) in conventional banks. This different mention is due to the fact that Islamic banking institutions do not use loans or loans, but rather use the term financing or financing. Whether or not a bank is liquid, if all debt obligations have been fulfilled and the customer's request for funds can be immediately approved without delay (Fadli, 2018).

The standard used by Bank Indonesia for the Financing to Deposit Ratio (FDR) is $80 \%$ to $110 \%$. If the Financing to Deposit Ratio (FDR) of a bank is below $80 \%$ (for example $60 \%$ ), it can 


\section{Nofinawati, Abdul Nasser Hasibuan, Dinda Sildya, Ferdy Kurniawan}

Comparative Analysis of Islamic Banking Financial Performance Before and During the Covid 19 Period in Indonesia

be concluded that the bank can only channel $60 \%$ of all the funds raised. This is because the main function of a bank is as an intermediary (intermediary) between parties with excess funds and those with shortages. If the Financing to Deposit Ratio (FDR) ratio is $60 \%$, it means that $40 \%$ of all collected funds are not distributed to parties in need, so it can be said that the bank is not performing its function properly. Then, if the bank's Financing to Deposit Ratio (FDR) reaches more than $110 \%$, it means that the total financing provided by the bank exceeds the funds raised. Because the funds collected from the public are small, it can be said that the bank is not performing its function as an intermediary party properly. The higher the Financing to Deposit Ratio (FDR), the more risky the bank's liquidity is, on the contrary, the lower the Financing to Deposit Ratio (FDR) indicates the lack of effectiveness of banks in channeling financing. If the bank's Financing to Deposit Ratio (FDR) is at the standard set by Bank Indonesia, the profit earned by the bank will increase (assuming the bank is able to channel its financing effectively) (Suryani, 2012).

Table 1. FDR Rating Criteria

\begin{tabular}{|l|l|}
\hline Composite Rating 1 & $50 \%<$ FDR $\leq 75 \%$ \\
\hline Composite Rating 2 & $75 \%<$ FDR $\leq 85 \%$ \\
\hline Composite Rating 3 & $85 \%<$ FDR $\leq 100 \%$ \\
\hline Composite Rating 4 & $100 \%<$ FDR $\leq 120 \%$ \\
\hline Composite Rating 5 & FDR $>120 \%$ \\
\hline
\end{tabular}

Source: SE Bank Indonesia No.6 / 23 / DPNP 2004*

\section{Net Profit}

Net profit is an important aspect in a bank because net income shows the extent to which the management of financial institutions has managed to organize its business. Losses that occur continuously will make it difficult for banks to develop, slow growth or reinvestment, so efforts to get external sources are increasingly difficult and expensive so that operational and financing risks increase (Nurahmi, 2017).

Net profit (net profit) is the profit that has been deducted by costs which are the company's expenses in a certain period, including taxes. The increase and decrease in profit can be seen from the profit growth. Profit growth is the increase and decrease in profits earned by the company compared to the previous year. Factors Affecting Net Profit Growth is The size of the company, The bigger the company, the higher the accuracy of the expected profit growth; Company age, Newly established companies lack experience in increasing profits, so the accuracy is still low; Leverage level, If the company has a high level of debt, managers tend to manipulate profits so as to reduce the accuracy of profit growth; Sales rate, The high level of sales in the past, the higher 
the level of sales in the future so that the profit growth will be higher; Past earnings changes, The greater the change in past earnings, the more uncertain the future profits will be.

\section{The elements of net profit}

There are several elements in net income (Jumingan, 2011), namely are Revenue, which is an inflow or increase in the assets of a company or a decrease in liabilities that occurs in an accounting period that comes from operating assets, in this case the sale of goods / credit which is the company's main business unit; Expenses, namely outflows or use of assets or increases in liabilities in an accounting period that occur in operating assets. According to the Indonesian Accounting Association, expenses are decreases in economic benefits during an accounting period in the form of outflows or decreases in assets or the occurrence of liabilities resulting in decreased equity which does not involve distribution to investors; Cost, which is cash or cash equivalent value sacrificed for goods or services that are expected to bring current and future benefits to the organization. Expired costs are called expenses. Each period expense is deducted from income in the income statement to determine profit for the period. Costs are outflows or use of assets or incurred debt (a combination of both) during a period that comes from the sale or production of goods, or the delivery of services or the performance of other activities that are the main activities of an entity; Profit-loss, is an increase / decrease in equity or net assets that comes from incidental transactions that occur in the company and all transactions or events that affect the company in an accounting period, other than those from the owner's investment income; Income, is the final result of calculating income and profit less expenses and losses in the period.

\section{Relationship of Each Variable with Covid 19}

This study conducted a comparative analysis of the financial performance of Islamic banking before and at the time of Covid 19 in Islamic banking in Indonesia. Farild, Miftha \& Fauziah Bachtiar (2020) who analyzed the comparison of the financial performance of PT. BNI Syariah Tbk before and during the Covid pandemic 19. Miftha Farild and Fauziah Bachtiar's research used the ratio of Return On Asset (ROA) \& Return On Equity (ROE) of PT. BNI Syariah Tbk. Their research shows that the performance of PT. BNI Syariah Tbk has experienced a slowing increase from the time before the Covid-19 Pandemic to the time when the Covid-19 Pandemic occurred.

\section{Methods}

This type of research is a quantitative comparison. The point is research that aims to compare the state or status of the phenomenon. This research uses quantitative data because in this research it is carried out by studying, analyzing, interpreting, and drawing conclusions from 
Nofinawati, Abdul Nasser Hasibuan, Dinda Sildya, Ferdy Kurniawan

Comparative Analysis of Islamic Banking Financial Performance Before and During the Covid

19 Period in Indonesia

the financial performance of Islamic banks in Indonesia. The selection of this type of research is in accordance with the research objectives, namely to determine the comparison of the financial performance of Islamic banks in Indonesia before and during the Covid-19 Pandemic.

The data used consists of CAR data, NPF, FDR, and Net Profit of Islamic Banks in Indonesia before and during Covid-19. The data source in this study is secondary data, namely financial report data from Islamic banks in Indonesia that have been published before and during the Covid-19 Pandemic. The object of this research is the monthly financial statements of Islamic banks in Indonesia starting from the six (6) month reporting period before Covid19 to the six (6) month reporting period during the covid19 period. The data is obtained from www.ojk.go.id which is in the Sharia Banking Statistics menu.

The population in this study is financial performance data in the form of CAR, NPF, FDR, and Net Profit obtained from Islamic Banking Statistics Data in Indonesia. The sampling method used was purposive sampling method, namely the sampling technique with certain considerations and criteria. The criteria are that the Financial Statements that are taken to be analyzed are monthly Financial Reports, which are six (6) months before Covid 19, starting from August 2019 to January 2020 and six (6) months during the Covid-19 period, namely February to the month July 2020. So the number of samples before and at the time of Covid 19 was 12 samples.

\section{Result And Discussion}

\section{Development of Islamic Bank Financial Performance 2015 to July 2020}

The financial performance of Islamic banks in Indonesia from 2015 to now has always increased every year. For more details, see the table below:

Table 2. Development of Sharia Bank Financial Performance in 2015 to 2020

\begin{tabular}{|c|c|c|c|c|c|c|}
\hline Year & $\begin{array}{c}\text { Market Share } \\
(\%)\end{array}$ & $\begin{array}{c}\text { CAR } \\
(\%)\end{array}$ & $\begin{array}{c}\text { NPF } \\
(\%)\end{array}$ & $\begin{array}{c}\text { FDR } \\
(\%)\end{array}$ & $\begin{array}{c}\text { ROA } \\
(\%)\end{array}$ & $\begin{array}{c}\text { Net Profit } \\
(\text { Milyar })\end{array}$ \\
\hline 2015 & 4,87 & 18,25 & 5,37 & 106,10 & 1,52 & 1786 \\
\hline 2016 & 5,34 & 18,85 & 5,42 & 101,59 & 1,61 & 2096 \\
\hline 2017 & 5,78 & 19,36 & 5,52 & 98,22 & 1,86 & 3084 \\
\hline 2018 & 5,96 & 20,36 & 4,90 & 98,89 & 1,73 & 5119 \\
\hline 2019 & 6,17 & 19,29 & 4,39 & 99,43 & 2,22 & 6278 \\
\hline 2020 & 6,48 & 25,12 & 4,46 & 93,72 & 1,74 & 5.508 \\
\hline
\end{tabular}

Source: www.ojk.go.id

Based on the table above, it can be seen and it is known that the financial performance of Islamic banks when viewed from a market share perspective, has always increased from 2015 to 2020 , reaching $6.17 \%$. However, in July 2020 the market share of Islamic banks decreased 
by $0.54 \%$. Likewise, the performance of Islamic banks when viewed in terms of the achievement of Net Profit from 2015 to 2019 has always increased to reach 6.278 trillion rupiah. However, in July 2020 the amount of Net Profit decreased from the previous year to 4.055 trillion rupiah. This can happen because the financial statements are still in the middle of 2020, namely July. However, if the performance of Islamic banks is seen in terms of CAR from 2015 to July 2020, it always increases every year. A different thing also happened when viewed from the ratio of NPF, FDR and ROA which fluctuated from 2015 to July 2020.

Following this, the development of Islamic bank financial performance will be seen more clearly in the chart below:

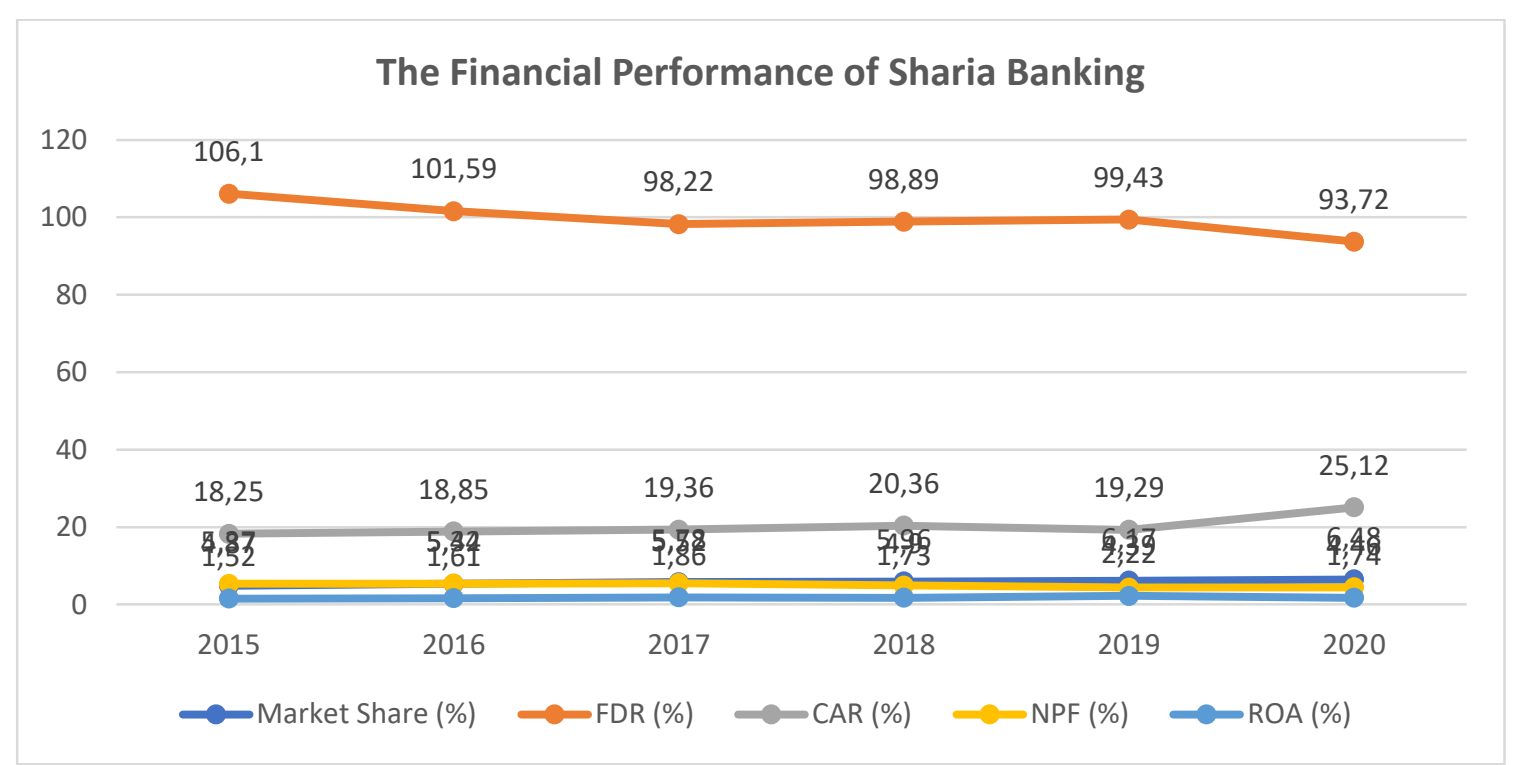

Figure 1. Sharia Bank Financial Performance Growth

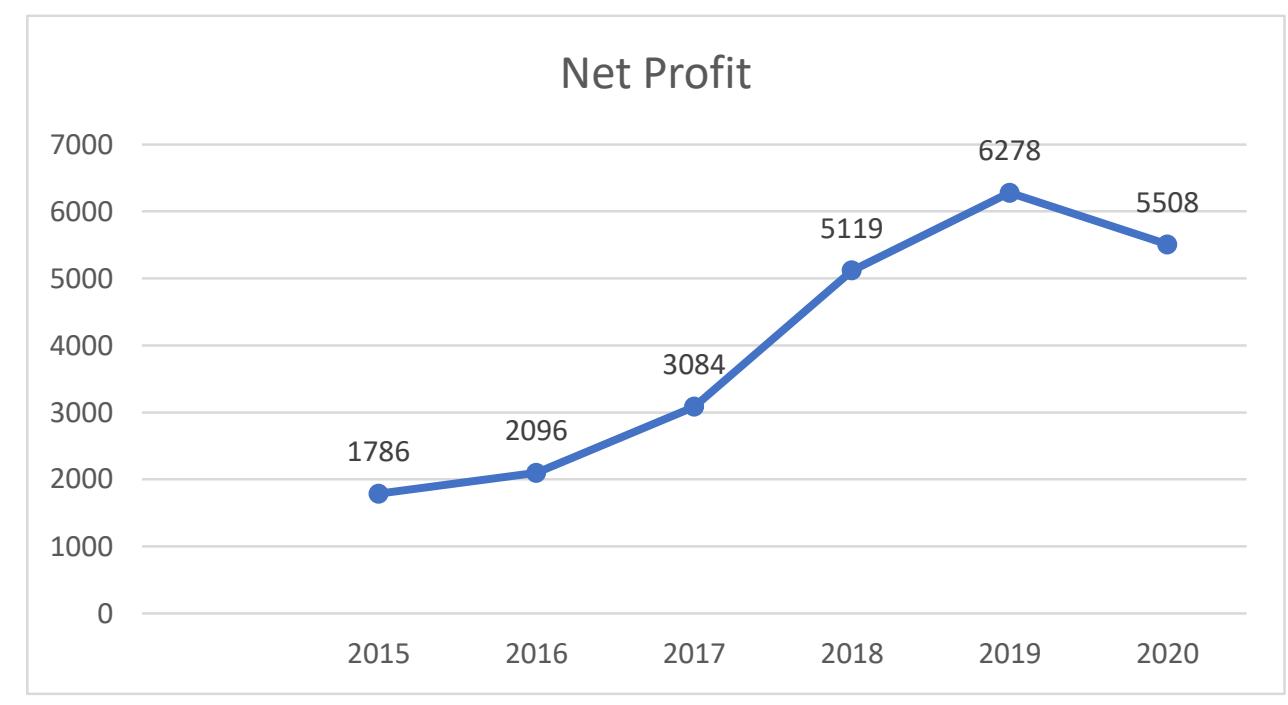

Figure 2. Net Profit

Based on the chart above, can be known that the performance of the financial bank sharia in terms of market share, ROA, NPF and Net Profit decreased in July 2020. It could be 
Nofinawati, Abdul Nasser Hasibuan, Dinda Sildya, Ferdy Kurniawan

Comparative Analysis of Islamic Banking Financial Performance Before and During the Covid

19 Period in Indonesia

happened because the period of its financial report in 2020 hasn't been a year. But even so CAR and FDR increased in July 2020.

\section{CAR Ratio of Shariah Bank Before and During Covid 19 in Indonesia}

The CAR ratio of Islamic banks in Indonesia before and during the covid 19 period can be seen in the table below:

Table 3. CAR of Sharia Bank

\begin{tabular}{|l|c|l|c|}
\hline \multicolumn{1}{|c|}{ Before Covid 19 } & CAR (\%) & During Covid 19 & CAR (\%) \\
\hline February 2019 & $\mathbf{2 0 , 3 0}$ & February 2020 & $\mathbf{2 0 , 4 7}$ \\
\hline March 2019 & $\mathbf{1 9 , 8 5}$ & March 2020 & $\mathbf{2 0 , 3 6}$ \\
\hline April 2019 & $\mathbf{1 9 , 6 1}$ & April 2020 & $\mathbf{2 0 , 4 7}$ \\
\hline May 2019 & $\mathbf{1 9 , 6 2}$ & May 2020 & $\mathbf{2 0 , 6 2}$ \\
\hline Juni 2019 & $\mathbf{1 9 , 5 6}$ & June 2020 & $\mathbf{2 1 , 2 0}$ \\
\hline July 2019 & $\mathbf{1 9 , 7 2}$ & July 2020 & $\mathbf{2 0 , 9 3}$ \\
\hline August 2019 & $\mathbf{2 0 , 3 6}$ & August 2020 & $\mathbf{2 0 , 3 7}$ \\
\hline September 2019 & $\mathbf{2 0 , 3 9}$ & September 2020 & $\mathbf{2 0 , 4 1}$ \\
\hline October 2019 & $\mathbf{2 0 , 5 4}$ & October 2020 & $\mathbf{2 0 , 4 1}$ \\
\hline November 2019 & $\mathbf{2 0 , 4 8}$ & November 2020 & $\mathbf{2 1 , 1 6}$ \\
\hline December 2019 & $\mathbf{2 0 , 5 9}$ & December 2020 & $\mathbf{2 1 , 6 4}$ \\
\hline January 2020 & $\mathbf{2 0 , 2 9}$ & January 2021 & $\mathbf{2 1 , 8 0}$ \\
\hline
\end{tabular}

Source: www.ojk.go.id

Based on the table above, it can be seen that the financial performance in terms of CAR before Covid 19 appeared, namely from August 2019 to January 2020, always experienced fluctuation. The CAR ratio increased by $0.03 \%$ in September 2019 when compared to the previous month. Then in October 2019 the CAR also increased by $0.15 \%$ from the previous month. Then in November 2019, CAR decreased by $0.06 \%$ from the previous month. Then in December 2019, CAR decreased by $0.3 \%$ from the previous month. Then in January 2020, CAR also decreased by $0.07 \%$ from the previous month.

However, the financial performance in terms of CAR during the Covid 19 period, from February 2020 to July 2020, also fluctuated. The CAR ratio decreased by $0.11 \%$ in March 2020 when compared to the previous month. Then in April 2020 the CAR increased by $0.11 \%$ from the previous month. Then in May 2020, CAR increased by $0.15 \%$ from the previous month. Then in June 2020, CAR decreased by $0.58 \%$ from the previous month. Then in July 2020, CAR also decreased by $0.27 \%$ from the previous month. 
For more details, the comparison of the financial performance of Islamic banks in Indonesia before and during the Covid 19 period, when viewed in terms of CAR, can be seen in the graph below:

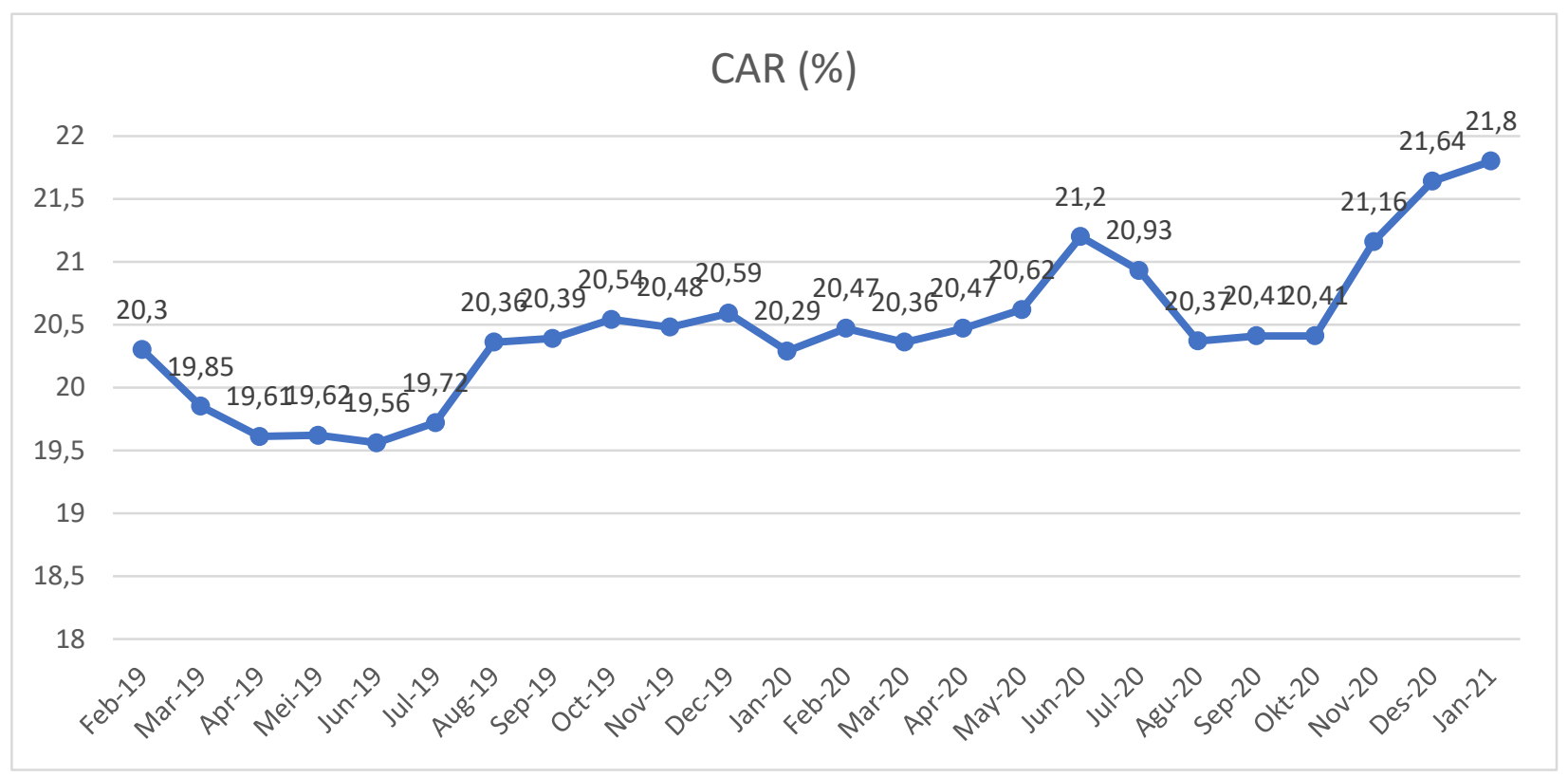

Figure 3. CAR Shariah Bank in Indonesia Before and During Covid 19

\section{The Comparison of Average CAR Growth Before and During Covid 19}

$$
\begin{aligned}
& \text { Average CAR Growth Before Covid } 19=\frac{0,03+0,15-0,06+0,11-0,3}{5}=\frac{-0,07}{5}=-0,014 \\
& \text { Average CAR Growth During Covid } 19=\frac{-0,11+0,11+0,15+0,58-0,27}{5}=\frac{0,46}{5}=0,092
\end{aligned}
$$

Based on the chart above it can be compared that the financial performance of Islamic banks is seen in terms of CAR ratios before the emergence of Covid 19 , the average CAR growth is -0.014 . From this figure, it can be understood that CAR growth before the emergence of Covid 19 , if on average, decreased by $0.014 \%$ every month. However, the average growth in the CAR ratio during the Covid 19 period was 0.092 . This positive value shows that the average growth in the CAR ratio during the Covid 19 period has increased by an average of $0.092 \%$ every month. So it can be compared that the average CAR growth before Covid 19 was smaller and had a negative value, that is, it always decreased. However, when Covid 19 the average CAR growth was greater and had a positive value, it tended to increase. 
Nofinawati, Abdul Nasser Hasibuan, Dinda Sildya, Ferdy Kurniawan

Comparative Analysis of Islamic Banking Financial Performance Before and During the Covid 19 Period in Indonesia

\section{NPF Ratio Of Shariah Bank Before and During Covid 19}

The NPF ratio of Islamic banks before and during the Covid 19 period can be seen in the table below:

Table 4. NPF of Sharia Bank

\begin{tabular}{|l|l|l|c|}
\hline \multicolumn{1}{|c|}{ Before Covid 19 } & NPF & During Covid 19 & NPF \\
\hline February 2019 & $\mathbf{3 , 4 4}$ & February 2020 & $\mathbf{3 , 3 8}$ \\
\hline March 2019 & $\mathbf{3 , 4 4}$ & March 2020 & $\mathbf{3 , 4 3}$ \\
\hline April 2019 & $\mathbf{3 , 5 8}$ & April 2020 & $\mathbf{3 , 4 1}$ \\
\hline May 2019 & $\mathbf{3 , 4 9}$ & May 2020 & $\mathbf{3 , 3 5}$ \\
\hline Juni 2019 & $\mathbf{3 , 3 6}$ & June 2020 & $\mathbf{3 , 3 4}$ \\
\hline July 2019 & $\mathbf{3 , 3 6}$ & July 2020 & $\mathbf{3 , 3 1}$ \\
\hline August 2019 & $\mathbf{3 , 4 4}$ & August 2020 & $\mathbf{3 , 3 0}$ \\
\hline September 2019 & $\mathbf{3 , 3 2}$ & September 2020 & $\mathbf{3 , 2 8}$ \\
\hline October 2019 & $\mathbf{3 , 4}$ & October 2020 & $\mathbf{3 , 1 8}$ \\
\hline November 2019 & $\mathbf{3 , 4 7}$ & November 2020 & $\mathbf{3 , 2 2}$ \\
\hline December 2019 & $\mathbf{3 , 2 3}$ & December 2020 & $\mathbf{3 , 1 3}$ \\
\hline January 2020 & $\mathbf{3 , 4 6}$ & January 2021 & $\mathbf{3 , 2 0}$ \\
\hline
\end{tabular}

Source: www.ojk.go.id

Based on the table above it can be seen that the financial performance in terms of NPF before Covid 19 appeared, namely from the month August 2019 to January 2020, always fluctuates. The NPF ratio decreased by $0.12 \%$ in September 2019 when compared to the previous month. Then in October 2019 the NPF also increased by 0.17\% from the previous month. Then in November 2019, the NPF decreased by $0.02 \%$ from the previous month. Then in December 2019, the NPF decreased by $0.24 \%$ from the previous month. Then in January 2020, the NPF also increased by $0.23 \%$ from the previous month.

However, the financial performance in terms of NPF during the Covid 19 period, from February 2020 to July 2020, also fluctuated. The NPF ratio decreased by $0.05 \%$ in March 2020 when compared to the previous month. Then in April 2020 the NPF decreased by $0.02 \%$ from the previous month. Then in May 2020, the NPF decreased by $0.06 \%$ from the previous month. Then in June 2020, the NPF decreased by $0.01 \%$ from the previous month. Then in July 2020, the NPF also decreased by $0.03 \%$ from the previous month.

For more details, the comparison of the financial performance of Islamic banks in Indonesia before and during the Covid 19 period can be seen in terms of NPF: 


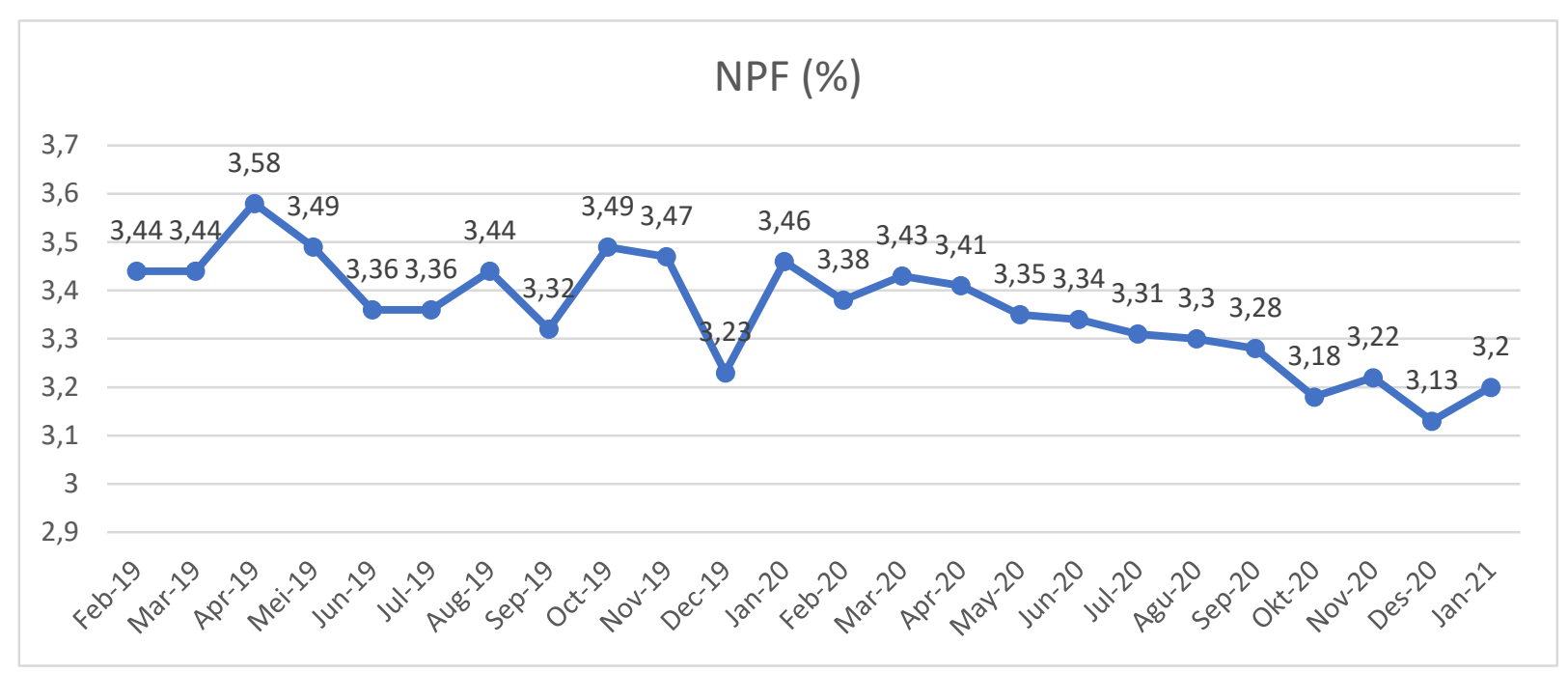

Figure 4. NPF Shariah Bank in Indonesia Before and During Covid 19

\section{The Comparison of Average NPF Growth Before and During Covid 19}

$$
\begin{aligned}
& \text { Average NPF Growth Before Covid } 19=\frac{0,03+0,15-0,06+0,11-0,3}{5}=\frac{-0,07}{5}=-0,014 \\
& \text { Average NPF Growth During Covid } 19=\frac{0,05-0,02-0,06-0,01-0,03}{5}=\frac{-0,07}{5}=-0,014
\end{aligned}
$$

Based on the graph above, it can be compared that the financial performance of Islamic banks is seen in terms of the NPF ratio before the emergence of Covid 19, The average NPF growth was smaller than the NPF during the Covid 19 period. From this figure, it can be understood that NPF growth before the emergence of Covid 19, if on average, decreased by 0.004\% every month. However, the average growth in the NPF ratio during the Covid 19 period was -0.014 . This negative value shows that the average growth in the NPF ratio during the Covid 19 period has decreased by an average of $0.014 \%$ each month. So it can be compared that the average NPF growth before and during the Covid 19 period was both negative, that is, decreased.

\section{FDR Ratio Of Shariah Bank Before and During Covid 19}

The FDR ratio of Islamic banks in Indonesia before and during the Covid 19 period can be seen in the table below:

Table 5. FDR of Sharia Bank

\begin{tabular}{|l|l|l|l|}
\hline \multicolumn{1}{|c|}{ Before Covid 19 } & FDR & \multicolumn{1}{|c|}{ During Covid 19 } & FDR \\
\hline February 2019 & $\mathbf{7 7 , 5 2}$ & February 2020 & $\mathbf{7 7 , 0 2}$ \\
\hline March 2019 & $\mathbf{7 8 , 3 8}$ & March 2020 & $\mathbf{7 8 , 9 3}$ \\
\hline April 2019 & $\mathbf{7 9 , 5 7}$ & April 2020 & $\mathbf{7 8 , 6 9}$ \\
\hline May 2019 & $\mathbf{8 2 , 0 1}$ & May 2020 & $\mathbf{8 0 , 5 0}$ \\
\hline Juni 2019 & $\mathbf{7 9 , 7 4}$ & June 2020 & $\mathbf{7 9 , 3 7}$ \\
\hline
\end{tabular}


Nofinawati, Abdul Nasser Hasibuan, Dinda Sildya, Ferdy Kurniawan

Comparative Analysis of Islamic Banking Financial Performance Before and During the Covid 19 Period in Indonesia

\begin{tabular}{|l|l|l|l|}
\hline July 2019 & $\mathbf{7 9 , 9 0}$ & July 2020 & $\mathbf{8 1 , 0 3}$ \\
\hline August 2019 & $\mathbf{8 0 , 8 5}$ & August 2020 & $\mathbf{7 9 , 5 6}$ \\
\hline September 2019 & $\mathbf{8 1 , 5 6}$ & September 2020 & $\mathbf{7 7 , 0 6}$ \\
\hline October 2019 & $\mathbf{7 9 , 1 0}$ & October 2020 & $\mathbf{7 7 , 0 5}$ \\
\hline November 2019 & $\mathbf{8 0 , 0 6}$ & November 2020 & $\mathbf{7 7 , 6 1}$ \\
\hline December 2019 & $\mathbf{7 7 , 9 1}$ & December 2020 & $\mathbf{7 6 , 3 6}$ \\
\hline January 2020 & $\mathbf{7 7 , 9 0}$ & January 2021 & $\mathbf{7 6 , 5 9}$ \\
\hline
\end{tabular}

Source: www.ojk.go.id

Based on the table above, it can be seen that financial performance in terms of FDR before Covid 19 appeared, namely from August 2019 to January 2020, always fluctuates. The FDR ratio increased by $0.71 \%$ in September 2019 when compared to the previous month. Then in October 2019 the FDR also decreased by 2.41\% from the previous month. Then in November 2019, the FDR increased by $0.96 \%$ from the previous month. Then in December 2019, the FDR decreased by $2.15 \%$ from the previous month. Then in January 2020 , the FDR also decreased by $0.01 \%$ from the previous month.

However, the financial performance in terms of FDR during the Covid 19 period, from February 2020 to July 2020, also fluctuated. The FDR ratio increased by $1.91 \%$ in March 2020 when compared to the previous month. Then in April 2020 the FDR decreased by $0.24 \%$ from the previous month. Then in May 2020, the FDR increased by $1.81 \%$ from the previous month. Then in June 2020, the FDR decreased by $1.13 \%$ from the previous month. Then in July 2020, the FDR also increased by $1.66 \%$ from the previous month.

For more details, the comparison of the financial performance of Islamic banks in Indonesia before and during the Covid 19 period, when viewed in terms of FDR, can be seen in the graph below:

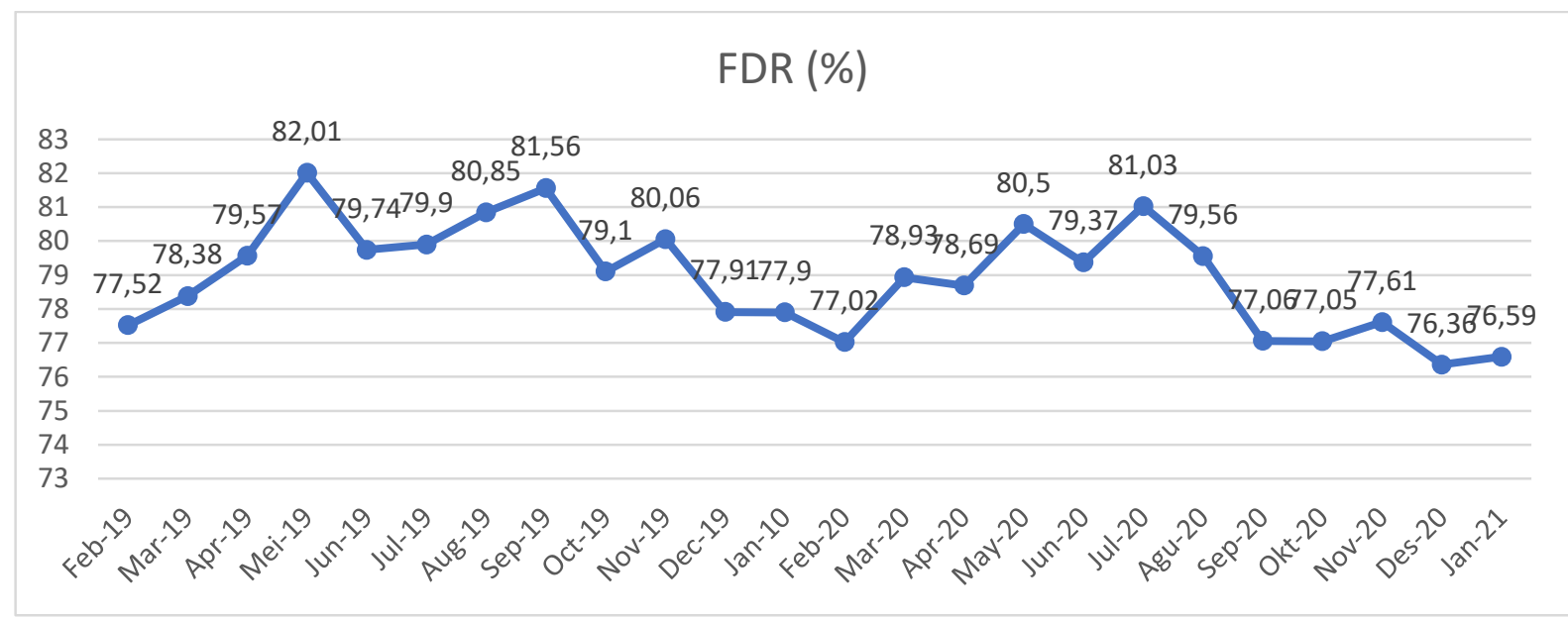

Figure 5. FDR Shariah Bank in Indonesia Before and During Covid 19 


\section{The Comparison of Average FDR Growth Before and During Covid 19}

$$
\begin{aligned}
& \text { Average FDR Growth Before Covid } 19=\frac{0,71-2,46+0,96-2,15-0,01}{5}=\frac{-2,95}{5}=-0,59 \\
& \text { Average FDR Growth During Covid } 19=\frac{1,91-0,24+1,81-1,13+1,66}{5}=\frac{4,01}{5}=0,802
\end{aligned}
$$

Based on the graph, it can be compared that the financial performance of Islamic banks is seen in terms of the FDR ratio before the emergence of Covid 19, on average -The average FDR growth is smaller when compared to the FDR during the Covid 19 period. From this figure it can be understood that the FDR growth before the emergence of Covid 19, if on average, decreased by $0.59 \%$ every month. However, the average growth in the FDR ratio during the Covid 19 period was $0.802 \%$. This positive value shows that the average growth in the FDR ratio during the Covid 19 period has increased by an average of $0.802 \%$ every month. So it can be seen that the comparison of the average FDR growth before and during the Covid 19 period was much different between before Covid 19 was negative, meaning that it tended to decline. Meanwhile, during the Covid 19 period, the average FDR growth was positive, which tended to increase. Even though Covid 19 is present in Indonesia, it does not interfere with the financial performance of Islamic banks in terms of liquidity, Islamic banks still reach liquid requirements.

\section{Total Net Profit Ratio Of Shariah Bank Before and During Covid 19}

Total Net Profit of Islamic banks in Indonesia before and during the Covid 19 period can be seen in the table below:

Table 6. Net Profit of Sharia Bank

\begin{tabular}{|l|c|l|c|}
\hline \multicolumn{1}{|c|}{ Before Covid 19 } & Net Profit & \multicolumn{1}{c|}{ During Covid 19 } & Net Profit \\
\hline February 2019 & $\mathbf{9 4 2}$ & February 2020 & $\mathbf{1 . 4 4 6}$ \\
\hline March 2019 & $\mathbf{1 . 5 6 8}$ & March 2020 & $\mathbf{2 . 1 8 7}$ \\
\hline April 2019 & $\mathbf{2 . 1 0 6}$ & April 2020 & $\mathbf{2 . 5 8 3}$ \\
\hline May 2019 & $\mathbf{2 . 6 7 8}$ & May 2020 & $\mathbf{3 . 0 0 5}$ \\
\hline Juni 2019 & $\mathbf{3 . 3 4 9}$ & June 2020 & $\mathbf{3 . 4 8 8}$ \\
\hline July 2019 & $\mathbf{3 . 9 6 1}$ & July 2020 & $\mathbf{4 . 0 5 5}$ \\
\hline August 2019 & $\mathbf{4 . 6 0 6}$ & August 2020 & $\mathbf{4 . 6 6 2}$ \\
\hline September 2019 & $\mathbf{5 . 1 9 4}$ & September 2020 & $\mathbf{5 . 2 9 0}$ \\
\hline October 2019 & $\mathbf{5 . 8 9 6}$ & October 2020 & $\mathbf{5 . 8 5 2}$ \\
\hline November 2019 & $\mathbf{6 . 6 7 2}$ & November 2020 & $\mathbf{6 . 2 9 8}$ \\
\hline December 2019 & $\mathbf{6 . 2 7 8}$ & December 2020 & $\mathbf{5 . 5 0 8}$ \\
\hline January 2020 & $\mathbf{7 3 8}$ & January 2021 & $\mathbf{7 8 0}$ \\
\hline
\end{tabular}

Source: www.ojk.go.id 
Nofinawati, Abdul Nasser Hasibuan, Dinda Sildya, Ferdy Kurniawan

Comparative Analysis of Islamic Banking Financial Performance Before and During the Covid 19 Period in Indonesia

Based on the table above, it can be seen that financial performance in terms of the amount of Net Profit earned by Islamic banks in Indonesia before Covid 19 appeared, from August 2019 to January 2020, it tended to increase. The amount of Net Profit has increased by Rp. 588 billion in September 2019 when compared to the previous month. Then in October 2019 the amount of Net Profit also increased by Rp. 702 billion from the previous month. Then in November 2019, the amount of Net Profit increased again by Rp. 776 billion from the previous month. Then in December 2019, the amount of Net Profit decreased by Rp. 394 billion from the previous month. Then in January 2020, the amount of Net Profit also decreased by Rp. 5,540 billion from the previous month. This occurs because the recording of the financial statements returns to the original period.

However, the financial performance in terms of the amount of Net Profit during the Covid 19 period, from February 2020 to July 2020, has always increased every month. The ratio of the amount of net profit has increased by Rp. 741 billion in March 2020 when compared to the previous month. Then in April 2020 the amount of Net Profit increased by Rp. 396 billion from the previous month. Then in May 2020, the amount of Net Profit has increased by Rp. 422 billion from the previous month. Then in June 2020, the amount of Net Profit has increased by Rp. 483 billion from the previous month. Then in July 2020, the amount of Net Profit also increased by Rp. 517 billion from the previous month.

For more details, the comparison of the financial performance of Islamic banks in Indonesia before and during the Covid 19 period when viewed in terms of the amount of Net Profit can be seen in the graph below:

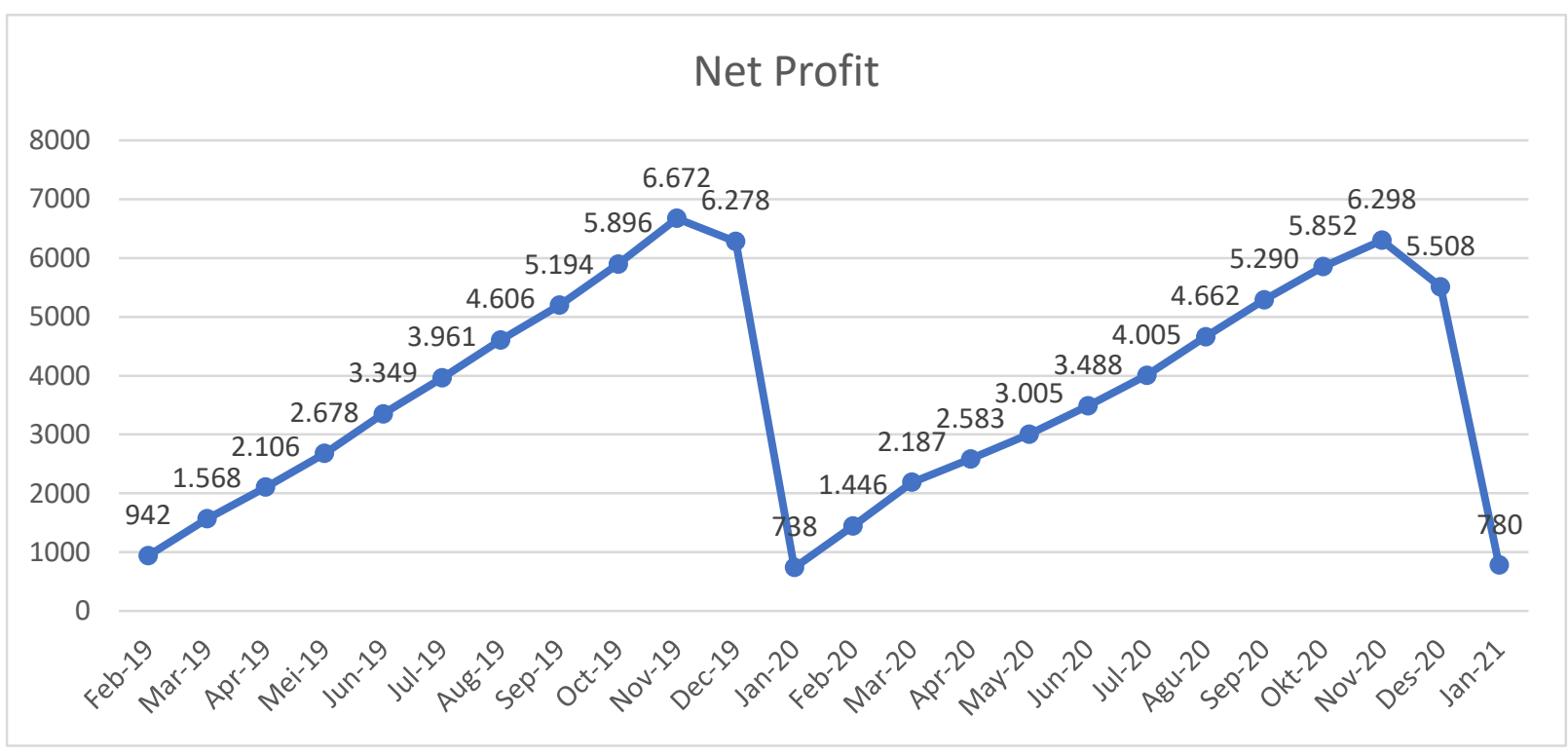

Figure 6. Net Profit Shariah Bank in Indonesia Before and During Covid 19 


\section{The Comparison of Average Net Profit Growth Before and During Covid 19}

$$
\begin{aligned}
& \begin{aligned}
\text { Average Net Profit Growth Before Covid } 19 & =\frac{588+702+776-394-5540}{5}=\frac{-3868}{5} \\
\qquad & =-773,6
\end{aligned} \\
& \text { Average Net Profit Growth During Covid } 19=\frac{741+396+422+483+517}{5}=\frac{2559}{5}=511,8
\end{aligned}
$$

Based on the graph, it can be compared that the financial performance of Islamic banks is seen in terms of the amount of Net Profit before the emergence of Covid. 19, the average growth in the amount of Net Profit is smaller when compared to the amount of Net Profit during the Covid 19 period. From this figure it can be understood that the growth in the amount of Net Profit before the emergence of Covid 19, if on average, decreased by Rp. 773.6 billion every month. However, the growth in the average net profit ratio during the Covid 19 period was Rp. 511.8 billion. This positive value shows that the average growth in the amount of Net Profit during the Covid 19 period has increased by an average of Rp. 511.8 billion every month. So it can be seen that the comparison of the average growth in the amount of Net Profit before and during the Covid 19 period was much different between before Covid 19 was negative, meaning that it tends to decline. Whereas during the Covid 19 period the average growth in the number of Net Profit was positive, which was always increasing. Although in Indonesia Covid 19 appears, it does not interfere with the financial performance of Islamic banks in Indonesia when viewed from the point of view of the amount of Net Profit that Islamic banks earn.

\section{Conclusion}

Based on the results of the discussion above, it can be seen that the comparison of the financial performance of Islamic banks before and during the Covid 19 period in Indonesia is as follows comparison of the financial performance of Islamic banks before and during the Covid 19 period when viewed in terms of the average CAR growth before Covid 19 was smaller and had a negative value, that is, it always decreased. However, when Covid 19 the average CAR growth was greater and had a positive value, it tended to increase. Comparison of the financial performance of Islamic banks before and during the Covid 19 period when viewed in terms of the average NPF growth before and during the Covid 19 period were both negative, namely experiencing a decline. Comparison of the financial performance of Islamic banks before and during the Covid 19 period, when viewed in terms of the average FDR growth before and during the Covid 19 period, it was far different from before Covid 19 was negative, meaning that it tends to decline. Meanwhile, during the Covid 19 period, the average FDR growth was positive, which tended to increase. Even though Covid 19 is present in Indonesia, it does not interfere with the financial performance of 


\section{Nofinawati, Abdul Nasser Hasibuan, Dinda Sildya, Ferdy Kurniawan}

Comparative Analysis of Islamic Banking Financial Performance Before and During the Covid 19 Period in Indonesia

Islamic banks in terms of liquidity, Islamic banks still reach liquid requirements. The comparison of the financial performance of Islamic banks before and during the Covid 1 period the average growth in the amount of Net Profit before and during the Covid 19 period was much different from before Covid 19 was negative, meaning that it tended to decline. Whereas during the Covid 19 period the average growth in the number of Net Profits was positive, which was always increasing. Even though in Indonesia Covid 19 appeared, it did not interfere with the financial performance of Islamic banks in Indonesia when viewed from the point of view of the amount of Net Profit obtained by Islamic banks.

\section{References}

Ahmad Agus Yasin Fadli, "Pengarub Financing to Deposit Ratio (FDR) dan Non-Performing Financing (NPF) terhadap Bagi HasilDeposito Mudharabah pada Bank. Syariah Mandiri, Jurnal Maksiprenuer", 2018,Vol. 8 No. 1,hlm 104

Angkoso, Pengarub Rasio Kenangan Terhadap Pertumbuban Laba Pada Perusahaan Industri Barang Konsumsi yang Terdaftar di BEI. Skripsi, Fakultas Ekonomi, Universitas Sumatera Utara

Anita Nurahmi, "Pertumbuhan Bagi Hasil, Dan Jual Beli Pada Peningkatan Laba Bersih Bank Umum Syari'ah", Jurnal Ekonomi Syariah dan Filantropi Islam,2017,Vol. 1, No. 2, hlm 4

Hasibuan, A. N., Lubis, A. F., Hasyim, S., \& Sadalia, I. (2017). Effects of auditor quality on marketbased and accounting-based financial statement quality and its impacts on economic consequences (a case on Indonesia capital market). International Journal of Economic Research. Vol. 14, No.12 (2017), pp. 205-230.

Putu Widhi Iswari dan Amanah, "Kinerja Kenangan Bank Umum Syariab: Negeri vs Swasta", Jurnal Islaminomic, Vol. 6 No.2, Agustus 2015, hal. 4.

Suryani. "Analisis Pengarub Financing to Deposit Ratio (FDR) Terbadap Profitabilitas Perbankan Syariah di Indonesia (Rasio Keuangan pada BUS dan UUS Periode 2008-2010)” ,Jurnal Manajemen Indonesia, 2012,Vol. 2 No. 2, hlm 158

Yuwita Ariessa Pravasanti, "Pengarub NPF Dan FDR Terbadap CAR Dan Dampaknya Terbadap ROA Pada Perbankan Syariah Di Indonesia”, Jurnal Ilmiah Ekonomi Islam, Vol. 4, No. 3, 2018, hal. 150. 